\title{
PENGARUH PENILAIAN PRESTASI KERJA PEGAWAI TERHADAP PENGEMBANGAN KARIR PADA KANTOR PENGAWASAN DAN PELAYANAN BEA DAN CUKAI TIPE B PEMATANGSIANTAR
}

\author{
Oleh: \\ Nur Insaini \\ S1 Manajemen \\ Darwin Lie, Marisi Butarbutar, Efendi
}

Abstraksi

Penulis mencoba mengambil judul Pengaruh Penilaian Prestasi Kerja Terhadap Pengembangan Karir Pegawai guna mengetahui hal-hal apa saja yang perlu diperbaiki dan dipertahankan agar mampu mengoptimalkan pengembangan karir pada KPPBC Tipe B Pematangsiantar. Metode penelitian yang digunakan adalah metode eksplanatori dimana sampel yang digunakan adalah seluruh pegawai KPPBC Tipe B Pematangsiantar yang berjumlah 20 orang. Hipotesis penelitian ini adalah penilaian prestasi kerja yang berpengaruh positif terhadap pengembangan karir pegawainya. Untuk mengukur pengembangan karir (Y) Penulis menyebarkan kuesioner kepada para pegawai sehingga diperoleh data deskriptif kualitatif dan deskriptif kuantitatif dan untuk mengukur prestasi kerja (X) diperoleh dari penilaian DP3 (Daftar Penilaian Pelaksanaan Pekerjaan).

Hasil analisis menunjukkan pengaruh positif variabel $\mathrm{X}$ terhadap variabel $\mathrm{Y}$ dengan persamaan regresi $\hat{Y}=0,67+0,98 X$. Kekuatan hubungan kedua variabel adalah sedang yaitu nilai $r$ sebesar 0,51 . Hal ini dikarenakan bukan hanya penilaian prestasi kerja yang menjadi faktor penentu pengembangan karir tetapi ada faktor lainnya seperti jenjang pendidikan pegawai. Dari perhitungan koefisien determinasi di atas menunjukkan bahwa pengembangan karir pegawai dapat dijelaskan oleh penilaian prestasi kerja sebesar 26,01\%, sedangkan $73,99 \%$ dijelaskan oleh faktor lain yang tidak dibahas dalam penelitan ini seperti diklat, jenjang pendidikan, pangkat/golongan dan lain-lain. Dari hasil pengolahan dan perhitungan data kuesioner, Penulis menyimpulkan bahwa penilaian prestasi kerja berpengaruh positif terhadap pengembangan karir pegawai KPPBC. Hal ini dibuktikan secara matematis melalui hipotesis, dimana hasil uji $t_{\text {hitung }}=2,52>t_{\text {tabel }}=2,10$. Dalam pengembangan karir pegawai diperlukan adanya penerapan penilaian prestasi kerja yang lebih efektif, terbuka, jujur dan adil sehingga para pegawai semakin meningkatkan kemampuan dan prestasi kerja mereka.

Kata kunci : Penilaian Prestasi Kerja dan Pengembangan Karir.

Abstraction

The author choose the title Influence Job Performance Assessment Against Employee Career Development to determine what are the things that need to be repaired and maintained to be able to optimize the career development of the Type B KPPBC Pematangsiantar.The research method used is explainatory method, where samples used were all employees KPPBC Type B Pematangsiantar totaling 20 people. The hypothesis of this study is that performance appraisal positive influence on the career development of employees. To measure career development (Y) Author distribute questionnaires to employees in order to obtain descriptive data and qualitative and quantitative descriptive to measure job performance $(X)$ obtained from DP3 assessment (Assessment Implementation Work List).

The results show a positive effect of the variable $X$ to variable $Y$ with regression equation $y=0.67+0.98$ $X$. Strength of the relationship between the two variables is currently the $r$ value of 0.51 . This is because not only the performance appraisal of factors to career development, but there are other factors such as education employees. From the above calculation of the coefficient of determination indicates that employee career development can be explained by the performance appraisal of $26.01 \%$, while $73.99 \%$ is explained by other factors not addressed in this research such as training, education, rank / grade and another-other. From the results of the questionnaire data processing and calculation, the author concludes that performance appraisal positive effect on employee career development KPPBC. It is proved mathematically through hypothesis, where the results of the test $t=2.52>t$ table $=2.10$. In the career development of employees required the implementation of performance appraisal are more effective, open, honest and fair so that employees increase their skills and work performance.

Keywords : Performance Appraisal and Career Development. 


\section{A. PENDAHULUAN}

\section{Latar Belakang Masalah}

Dalam rangka usaha mencapai tujuan nasional yaitu mewujudkan masyarakat adil dan makmur diperlukan adanya PNS yang bermutu tinggi dan sadar akan tugas dan tanggung jawabnya. Untuk itu, Pemerintah membentuk suatu undangundang. Undang-undang tersebut mengatur kedudukan, kewajiban, hak dan pembinaan Pegawai Negeri, yaitu UU nomor 8 tahun 1974 dan terakhir dengan UU nomor 43 tahun 1999 tentang Pokokpokok Kepegawaian yang titik beratnya mulai diarahkan pada prestasi kerja PNS yang digunakan instansi untuk mengevaluasi kinerja pekerjaan seseorang.

KPPBC Tipe B Pematangsiantar yang berlokasi di Jalan Sisingamangaraja No. 66 Pematangsiantar memiliki pegawai sebanyak 20 orang. Instansi yang bertugas untuk melayani perusahaan yang bergerak dalam bidang investasi atau impor dan ekspor barang ini memberikan keleluasaan pada pegawai untuk mengembangkan potensi dirinya melalui program pengembangan karir. Secara bertahap KPPBC Tipe B Pematangsiantar mengadakan pendidikan dan latihan yang berkaitan dengan pengembangan karir yang dipersiapkan untuk menduduki jabatan tertentu.

Melalui pengamatan sementara penulis selama melakukan penelitian pada KPPBC Tipe B Pematangsiantar bahwa masih terdapatnya permasalahan menyangkut kesempatan pegawai dalam mendapatkan pengembangan karir. Hal tersebut cenderung mengacu terhadap kurangnya perhatian bagi sebagian pegawai lama/senior, dimana mereka merasa kurangnya penghargaan atas kontribusi yang telah lama mereka kerjakan jika nantinya banyak pegawai baru yang dipromosikan. Hal ini akan memberikan suatu gambaran kesimpangsiuran mengenai bagaimana jenjang karir mereka nantinya.

Dalam pengembangan karir pegawainya, KPPBC Tipe B Pematangsiantar melakukan penilaian prestasi kerja pegawainya dengan menggunakan indikator yang meliputi kesetiaan para pegawai terhadap instansi tempatnya bekerja, penilaian prestasi kerja pegawainya, tanggung jawab pegawai terhadap pekerjaanya, ketaatan pegawai dalam mematuhi peraturan perundang-undangan, kejujuran pegawai dalam melaksanakan tugasnya, kerja sama pegawai dalam menyelesaikan tugas, prakarsa yaitu kemampuan pegawai dalam mengambil keputusan, dan kepemimpinan menurut SE. BAKN No. 02/SE/1980 bagian III poin 1. Penilaian prestasi kerja tersebut dilakukan setiap akhir tahun yaitu pada bulan Desember dengan sistem penilaian DP3 (Daftar Penilaian Pelaksanaan Pekerjaan). Dalam Peraturan Pemerintah ini ditentukan, bahwa yang berwenang membuat penilaian prestasi kerja PNS adalah pejabat penilai, yaitu atasan langsung dari PNS yang bersangkutan dengan ketentuan paling rendah pejabat eselon $\mathrm{V}$ atau pejabat lain yang ditentukan.

\section{Rumusan Masalah}

a. Bagaimana gambaran penilaian prestasi kerja dan pengembangan karir pegawai pada Kantor Pengawasan dan Pelayanan Bea dan Cukai Tipe B Pematangsiantar?

b. Seberapa besar pengaruh penilaian prestasi kerja terhadap pengembangan karir pegawai pada Kantor Pengawasan dan Pelayanan Bea dan Cukai Tipe B Pematangsiantar?

\section{Tujuan Penelitian}

a. Untuk mengetahui gambaran penilaian prestasi kerja pegawai dan pengembangan karir pegawai pada Kantor Pengawasan dan Pelayanan Bea dan Cukai Tipe B Pematangsiantar.

b. Untuk mengetahui besarnya pengaruh penilaian prestasi kerja terhadap pengembangan karir pegawai pada Kantor Pengawasan dan Pelayanan Bea dan Cukai Tipe B Pematangsiantar.

\section{Metode Penelitian}

Desain penelitian merupakan suatu cara yang sistematis dan objektif dengan maksud untuk memperoleh data atau mengumpulkan keterangan untuk diteliti. Adapun Desain penelitian yang digunakan dalam penulisan skripsi ini adalah Penelitian Kepustakaan (Library Research) dan Penelitian Lapangan (Field Research).

Teknik pengumpulan data yang dilakukan penulis dalam penelitian ini adalah berupa Kuesioner, Wawancara dan Dokumentasi. Adapun jenis data yang digunakan dalam penelitian ini adalah jenis data kualitatif dan data kuantitatif. Hasil data yang diperoleh dari lapangan akan dianalisis secara deskriptif baik bersifat kualitatif dan kuantitatif.

\section{B. LANDASAN TEORI}

Menurut Hariandja (2002:5) manajemen sumber daya manusia adalah perencanaan, pengorganisasian, pengarahan dan pengawasan kegiatan-kegiatan pengadaan, pengembangan, pemberian kompensasi, pengintegrasian, pemeliharaan dan pelepasan sumber daya manusia agar tercapai tujuan organisasi dan masyarakat.

Adapun fungsi manajemen sumber daya manusia menurut Mondy (2008:5) pada dasarnya ada lima jenis yaitu:

1. Penyediaan staf

Merupakan proses yang menjamin suatu organisasi untuk selalu memiliki jumlah karyawan yang tepat dengan keahlian-keahlian yang memadai dalam pekerjaan-pekerjaan tepat pada waktunya untuk mencapai tujuan organisasi.

2. Pengembangan sumber daya manusia

Fungsi manajemen sumber daya manusia utama yang tidak hanya terdiri atas pelatihan dan pengembangan namun juga aktivitas-aktivitas perencanaan dan pengembangan karier individu, organisasi, serta manajemen dan penilaian kinerja.

3. Kompensasi 
Suatu sistem kompensasi yang terencana matang memberi para karyawan imbalan-imbalan yang layak dan adil atas kontribusi mereka dalam mencapai tujuan-tujuan organisasi.

4. Kesehatan Dan Keselamatan

Keselamatan adalah perlindungan bagi para karyawan yang disebabkan kecelakaankecelakaan yang terkait dengan pekerjaan. Kesehatan adalah bebasnya para karyawan dari sakit fisik atau emosi.

5. Hubungan Kekaryawanan dan Perburuhan Hubungan karyawan dengan pihak perusahaan harus lah dijaga dengan baik agar karyawan lebih termotivasi untuk mencapai tujuan perusahaan yang telah ditetapkan

Nasution (2004:91) berpendapat bahwa penilaian prestasi kerja adalah proses penilaian yang dilakukan oleh organisasi terhadap karyawannya secara sistematik dan formal berdasarkan pekerjaan yang ditugaskan kepadanya. Penilaian pelaksanaan pekerjaan perlu dilakukan secara formal berdasarkan serangkaian kriteria yang ditetapkan secara rasional serta diterapkan secara objektif serta didokumentasikan secara sistematik.

Hasibuan (2003:91) menyatakan bahwa terdapat dua kelompok penilaian, yaitu:

1. Penilai informal adalah penilai yang melakukan penilaian mengenai kualitas kerja dan pelayanan yang diberikan oleh masing-masing karyawan baik atau buruk. Penilai ini adalah konsumen dan atau rekanan.

2. Penilai formal adalah suatu komite yang mempunyai wewenang formal menilai bawahannya di dalam maupun di luar pekerjaan dan berhak menetapkan kebijakan. Selanjutnya terhadap setiap individu karyawan. Penilai formal ini dibedakan atas penilai individu yaitu seorang atasan langsung yang secara individual menilai perilaku dan prestasi setiap karyawan yang menjadi bawahannya, apakah baik, sedang atau buruk. Sedangkan penilai kolektif adalah suatu tim/kolektif secara bersama-sama melakukan penilaian prestasi kerja karyawan dan menetapkan kebijakan selanjutnya terhadap karyawan tersebut.

Menurut Rivai (2009:264), Karir terdiri dari semua pekerjaan yang ada selama seseorang bekerja, atau dapat dikatakan bahwa karir adalah seluruh jabatan yang diduduki seseorang dalam kehidupan kerjanya. Dapat disimpulkan bahwa karir adalah semua urutan aktivitas atau kegiatan yang berhubungan dengan pekerjaan atau jabatan dan perilaku yang pernah dijalani atau diduduki seseorang sepanjang kehidupan kerjanya, yang merupakan sejarah hidupnya dalam bekerja.

Menurut Tanjung dan Arep (2002:8) pengembangan karir memiliki beberapa manfaat yaitu sebagai berikut:

1. Mendorong para karyawan untuk mengembangkan diri dan kemampuannya.

2. Menambah rasa kepedulian yang tinggi terhadap perusahaan.
3. Mencegah terjadinya keresahan di kalangan karyawan yang selama ini kurang diperhatikan.

4. Mengurangi karyawan yang meninggalkan perusahaan.

5. Mengisi lowongan yang tersedia, akibat adanya karyawan yang mutasi atau promosi.

6. Mengoptimalkan penggunaan pengetahuan, kemampuan dan keterampilan karyawan, sesuai dengan potensi yang bersangkutan.

Menurut Tanjung dan Arep (2002:10) faktorfaktor penghambat pengembangan karir antara lain:

1. Kekurangan biaya, sebab pengembangan karir menghendaki pendanaan yang besar, yang bisa menjadi tambahan beban biaya bagi perusahaan.

2. Kesukaran untuk menyusun pola pikir yang tepat, sebab belum jelas arah pengembangan karir.

3. Kemampuan bagian SDM yang masih terbatas dalam menafsirkan hakikat pengembangan karir.

4. Sulitnya menginventarisasi para karyawan yang tepat untuk pengembangan karirnya secara tepat.

Penilaian prestasi kerja merupakan proses kegiatan yang dilakukan untuk mengevaluasi tingkat pelaksanaan pekerjaan seseorang, Saydam (2005:85). Penilaian prestasi kerja ini bertujuan untuk membantu manajemen sumber daya manusia dalam mengambil keputusan yang berhubungan dengan kepegawaian seperti untuk pengembangan karir.

Pengembangan karir adalah proses peningkatan kemampuan kerja individu yang dicapai dalam rangka mencapai karir yang diinginkan, Rivai (2009:274). Pengembangan karir merupakan hal yang sangat penting karena dapat membantu pencapaian tujuan organisasi dan juga pencapaian tujuan pegawai dalam pekerjaannya. Untuk melaksanakan hal tersebut, pengelola SDM perlu untuk melakukan penilaian prestasi kerja agar mempermudah pihak pengelola SDM dalam mendapatkan informasi mengenai kelebihan dan juga kekurangan dari pegawainya agar tujuan-tujuan dan keinginan dari pegawai dan organisasi dapat tercapai dengan baik.

\section{PEMBAHASAN}

1. Analisa

\section{a. Analisa Deskriptif Kualitatif}

Penulis ingin menganalisis dan mengevaluasi mengenai seberapa pentingnya penilaian prestasi kerja dalam pengembangan karir pegawai pada Kantor Pengawasan dan Pelayanan Bea dan Cukai Tipe B Pematangsiantar. Analisis deskriptif dimaksudkan untuk mendapatkan gambaran/deskripsi mengenai tanggapan dari responden mengenai penilaian prestasi kerja dan pengembangan karir pada Kantor Pengawasan dan Pelayanan Bea dan Cukai Tipe B Pematangsiantar.

Penilaian prestasi kerja diterapkan dengan memperhatikan indikator-indikator penilaian prestasi kerja seperti, kesetiaan pegawai, prestasi kerja, tanggung jawab, ketaatan, kejujuran, kerja sama, prakarsa dan kepemimpinan. Melalui sistem penilaian prestasi kerja ini, diharapkan mampu 
menghasilkan informasi yang dapat membantu dalam hal pengembangan karir pegawai yang diukur melalui indikator prestasi kerja yang memuaskan, pengenalan oleh pihak lain, kesetiaan pada organisasi, kesempatan untuk bertumbuh dan berhenti atas permintaan dan kemauan sendiri. Selain untuk pengembangan karir, penilaian prestasi kerja bermanfaat untuk perbaikan kinerja pegawai, penyesuaian kompensasi, keputusan dalam penempatan, kebutuhan pelatihan dan pengembangan, perencanaan karir, defesiensi proses penempatan staf, ketidakakuratan informasi, kesalahan rancangan pekerjaan, kesempatan kerja yang sama, tantangan-tantangan eksternal dan umpan balik pada SDM.

Berdasarkan hal tersebut, maka penulis menganalisa dan mengevaluasi berdasarkan teoriteori, catatan yang berhubungan dengan judul penelitian dan keadaan pada Kantor Pengawasan dan Pelayanan Bea dan Cukai Tipe B Pematangsiantar. Selain itu, Penulis juga menyebarkan kuesioner kepada para pegawai yang berisi pertanyaan tentang indikator tentang pengembangan karir pegawai.

1) Penilaian Prestasi Kerja

Dalam memotivasi pegawai dalam pelaksanaan pekerjaannya, Kantor Pengawasan dan Pelayanan Bea dan Cukai Tipe B Pematangsiantar melakukan penilaian prestasi kerja, khususnya keinginan para pegawainya untuk mengembangkan karir mereka. Keinginan untuk mengembangkan karir diharapkan mampu mendorong pegawai untuk senantiasa meningkatkan prestasi kerja mereka dan lebih loyal terhadap instansi agar tercapai efektifitas dan efisiensi kerja.

\section{2) Pengembangan Karir}

Pengembangan karir merupakan harapan untuk meraih posisi atau jabatan yang lebih tinggi atau lebih baik dari posisi atau jabatan sebelumnya. Pada Kantor Pengawasan dan Pelayanan Bea dan Cukai Tipe B Pematangsiantar, pengembangan karir dilaksanakan dengan melihat kemampuan pegawai dan kelebihan pegawai dalam hal pekerjaan. Berdasarkan indikator pengembangan karir meliputi prestasi kerja yang memuaskan, pengenalan oleh pihak lain, kesetiaan pada organisasi, kesempatan untuk bertumbuh dan berhenti atas permintaan dan kemauan sendiri.

Pengembangan karir ditujukan agar mendorong para karyawan untuk mengembangkan diri dan kemampuannya, menambah rasa kepedulian yang tinggi terhadap perusahaan, mencegah terjadinya keresahan di kalangan karyawan yang selama ini kurang diperhatikan, mengurangi karyawan yang meninggalkan perusahaan, mengisi lowongan yang tersedia akibat adanya karyawan yang mutasi atau promosi dan mengoptimalkan penggunaan pengetahuan, kemampuan dan keterampilan karyawan sesuai dengan potensi yang bersangkutan. Dalam pengembangan karir tidak selamanya berjalan mulus sesuai keinginan pegawai. Hal ini dikarenakan adanya beberapa hambatan bagi pengembangan karir yang berasal dari lingkungan internal dan eksternal.
Adapun hambatan-hambatan yang terjadi seperti semakin tingginya tuntutan akan kesesuaian antara kemampuan karyawan dan kebutuhan pekerjaan dalam organisasi, tingginya kompleksitas tuntutan akan kemampuan beradaptasi pekerja terhadap aplikasi teknologi baru, tingginya tuntutan spesifikasi pendidikan dan permintaan akan pengetahuan serta keahlian tehnis yang harus dimiliki pekerja, semakin terspesialisasinya pendidikan sehingga mengarah pada stratifikasi horizontal dalam organisasi dan membatasi mobilitas karir secara vertikal, keterbatasan prospek karir dan keanekaragaman pengalaman kerja yang melibatkan pertumbuhan intelektual dan psikologikal karyawan dalam perjalanan karir, kurangnya pengalaman terutama pengalaman yang spesifik sehingga akan mengurangi penawaran akan orang-orang yang memiliki pemahaman sepenuhnya tentang organisasi agar bisa menjadi pemimpin yang efektif dan ketidakmampuan organisasi memenuhi harapan promosi setiap karyawan, karena banyaknya hambatan yang muncul terhadap pengembangan karir organisasi.

\section{b. Analisa Deskriptif Kuantitatif}

Dalam analisis deskriptif kuantitatif, penulis akan menganalisis besarnya pengaruh antara penilaian prestasi kerja (X) terhadap pengembangan karir (Y) melalui analisis regresi. Selanjutnya adalah melakukan analisis korelasi untuk mengukur kuatnya hubungan antara dua variabel atau lebih. Pada penelitian ini dibahas tentang pengaruh penilaian prestasi kerja pegawai terhadap pengembangan karir.

Untuk mengetahui pengaruh penilaian prestasi kerja terhadap pengembangan karir maka dilakukan perhitungan secara manual untuk memperoleh nilai a dan $\mathrm{b}$, yaitu:

$$
\begin{aligned}
& \mathrm{b}=\frac{n t x y-t x X)(Z Y)}{n I x^{2}-(\tau x)^{2}} \\
& \mathrm{~b}=\frac{(20)[16964]-(2 / 1)(2 / 6)}{(20)(10904)-[2 / 1)^{2}} \\
& \mathrm{~b}=\frac{32 / 280-4 . / 18 \mathrm{a}}{726140-326041} \\
& \mathrm{~b}=\frac{\mathrm{y} /}{44} \\
& \mathrm{~b}=0,98
\end{aligned}
$$
sebagai berikut:

$$
\begin{aligned}
& \mathrm{a}=(\Sigma Y-b \Sigma X] / n \\
& \mathrm{a}=[(573)-(0,98)(571)] / 20
\end{aligned}
$$$$
\mathrm{a}=0,67
$$

Maka model regresi liniernya menjadi $\hat{Y}=$ 0,67+0,98 X, maka dapat diartikan bahwa penilaian prestasi kerja berpengaruh positif pada pengembangan karir. Dimana apabila pelaksanaan penilaian prestasi kerja semakin optimal, maka pengembangan karir akan semakin baik pula.

Analisis distribusi frekuensi jawaban responden menurut skor dari variabel $\mathrm{X}$ (Penilaian Prestasi Kerja) dan Y (Pengembangan Karir) dimaksud sebagaimana yang telah dilakukan, 
hanyalah bermanfaat untuk memberikan informasi pendahuluan mengenai pola distribusi jawaban responden menurut skor. Selanjutnya dilakukan perhitungan korelasi berupa derajat atau kekuatan hubungan fungsional yang menjelaskan hubungan antar perubah, dinyatakan dengan yang dinamakan koefisien korelasi yang sering disimbolkan dengan $r$. Nilai $r$ dapat dihitung sebagai berikut:

$$
\begin{aligned}
& r \quad=\frac{n(I X Y)-[I z)(I Y)}{\sqrt{\pi 2 x^{2}-(2 x)^{2} \sqrt{\pi I z^{2}-(z y)^{2}}}} \\
& r=\frac{20[16364)-[571](0 / d)}{\sqrt{20(16107)-(571)^{2} \sqrt{20(16415)-(571)^{2}}}}
\end{aligned}
$$

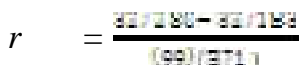

$$
\begin{aligned}
& r=\frac{y / 21}{291.098110} \\
& r=0,51
\end{aligned}
$$

Dari hasil perhitungan di atas, dapat diketahui bahwa terdapat hubungan yang sedang dan positif antara penilaian prestasi kerja terhadap pengembangan karir pegawai pada Kantor Pengawasan dan Pelayanan Bea dan Cukai Tipe B Pematangsiantar. Hal ini dapat dilihat pada tabel 2 Kriteria Tingkat Hubungan Antar Variabel.

Hubungan yang sedang dan positif tersebut terjadi dikerenakan bukan hanya penilaian prestasi kerja yang menjadi faktor penentu pengembangan karir tetapi ada faktor lainnya seperti jenjang pendidikan pegawai. Oleh sebab itu, tidak semua pegawai bisa mendapatkan kesempatan diklat walaupun hasil penilaian preatasi kerjanya baik karena terdapat standar pendidikan tertentu untuk menjadi peserta diklat.

Selanjutnya untuk mengukur seberapa besar variabel bebas (Penilaian Prestasi Kerja) menjelaskan variabel terikat (Pengembangan Karir) maka digunakan koefisien determinasi (KD). Nilai KD dapat diperoleh dari:

$$
\begin{aligned}
& \mathrm{KD}=\mathrm{r}^{2} \times 100 \% \\
& \mathrm{KD}=(0,51)^{2} \times 100 \% \\
& \mathrm{KD}=0,2601 \times 100 \% \\
& \mathrm{KD}=26,01 \% .
\end{aligned}
$$

Dari hasil perhitungan di atas, dapat diketahui bahwa penilaian prestasi kerja menjelaskan tinggi rendahnya pengembangan karir pegawai yaitu sebesar 26,01\%, sedangkan sisanya 73,99\% dipengaruhi oleh faktor lain seperti diklat, jenjang pendidikan, pangkat/golongan dan faktor-faktor lainnya yang tidak dibahas dalam penelitian ini.

Uji $t$ digunakan untuk menguji pengaruh variabel bebas terhadap variabel terikat secara parsial atau individual. Untuk menguji hasil perhitungan regresi dapat dilakukan pembuktian hipotesa untuk mengetahui apakah variabel bebas mempunyai pengaruh atau tidak terhadap variabel terikat secara Parsial. Adapun hipotesa yang akan diuji secara parsial adalah:

1) Menentukan Hipotesa

a) $\mathrm{Ho}=0$, bahwa tidak terdapat pengaruh yang positif antara penilaian prestasi kerja terhadap pengembangan karir pada Kantor Pengawasan dan Pelayanan Bea dan Cukai Tipe B Pematangsiantar. b) $\mathrm{Ha} \neq 0$, bahwa terdapat pengaruh yang positif antara penilaian prestasi kerja pegawai terhadap pengembangan karir pada Kantor Pengawasan dan Pelayanan Bae dan Cukai Tipe B Pematangsiantar. Dengan kriteria pengujian yaitu:

a) Jika $t_{\text {hit }}<t_{\text {tab }}$ atau probabilitas signifikansi $<$ $\alpha(5 \%)$, maka Ho diterima dan Ha ditolak.

b) Jika $t_{\text {hit }}>t_{\text {tab }}$ atau probabilitas signifikansi $>\alpha$ (5\%), maka Ho ditolak dan Ha diterima.

2) Persentase $\alpha$ ditentukan sebesar $5 \%$

Jumlah sampel $(\mathrm{n})=20$

Derajat kebebasan $(\mathrm{dk})=\mathrm{n}-2$

$$
\begin{aligned}
& =20-2 \\
& =18
\end{aligned}
$$
berikut

Kemudian dapat dihitung nilai $\mathbf{t}$ hit sebagai

$$
\begin{aligned}
& \mathrm{t}_{\text {hit }}=\frac{\mathrm{r} \sqrt{\mathrm{n-2}}}{\sqrt{1-r^{2}}} \\
& \mathrm{t}_{\text {hit }}=\frac{\sin \sqrt{20-2}}{\sqrt{1-0,2601}} \\
& \mathrm{t}_{\text {hit }}=\frac{0,21 \sqrt{18}}{\sqrt{1-0,2601}} \\
& \mathrm{t}_{\text {hit }}=\frac{2.20 \mathrm{a} / \mathrm{a}}{0.800 \mathrm{I} /} \\
& \mathrm{t}_{\text {hit }}=2,52
\end{aligned}
$$

Sedangkan $\mathbf{t}_{\text {tab }}$ derajat kebebasan 18 (interpolasi) dapat dihitung sebagai berikut:

$$
\begin{aligned}
& \mathrm{t}_{(5 \% ; 15)}=2,1314 \\
& \mathrm{t}_{(5 \% ; 20)}=2,086 \\
& \frac{\mathrm{E}}{\mathrm{a}}=\frac{x}{0.0434} \\
& 5 \mathrm{x} \quad=0,1362 \\
& \mathrm{x} \quad=0,1362 / 5 \\
& \mathrm{x} \quad=0,02724
\end{aligned}
$$

Maka, $\mathrm{t}_{(5 \% ; 18)}=2,13-0,02$

Dari perhitungan diatas tersebut diperoleh hasil $t_{\text {hit }} 2,52>t_{\text {tab }} 2,10$. Jika $t_{\text {hitung }}>t_{\text {tabel }}$ maka Ho ditolak dan $\mathrm{Ha}$ diterima, artinya adanya pengaruh positif antara penilaian prestasi kerja (X) terhadap pengembangan karir pegawai $(\mathrm{Y})$. Hal ini berarti bahwa penilaian prestasi kerja pada Kantor Pengawasan dan Pelayanan Bea dan Cukai Tipe B Pematangsiantar berpengaruh secara positif terhadap pengembangan karir pegawai, sehingga hipotesis $\left(\mathrm{H}_{\mathrm{a}}\right)$ yang diajukan penulis adalah dapat diterima.

\section{Evaluasi}

\section{a. Penilaian Prestasi Kerja KPPBC Tipe B Pematangsiantar}

Pada dasarnya penilaian prestasi kerja pada kantor KPPBC Tipe B Pematangsiantar sudah menunjukkan nilai yang baik. Hanya saja untuk lebih meningkatkan prestasi kerja perlu diadakannya peningkatan-peningkatan pada setiap indikator yang dinilai pada penilaian prestasi kerja. Berdasarkan indikator penilaian prestasi kerja yang digunakan untuk mengukur bagaimana pelaksanaan penilaian prestasi kerja yang ada pada Kantor Pengawasan dan Pelayanan Bea dan Cukai Tipe B Pematangsiantar, 
maka hasil penelitian ini dapat dijelaskan sebagai berikut. Pada indikator kesetiaan, hasil perhitungan nilai rata-ratanya mendapatkan jawaban dengan kriteria baik. Hal ini dikarenakan kesetiaan bekerja akan membawa dampak baik terhadap kemajuan karir mereka dalam instansi tersebut.

Selanjutnya, pada indikator prestasi kerja, dapat dilihat nilai rata-rata responden mendapatkan nilai rata-ratanya dengan kriteria baik. Hal ini dikarenakan kemampuan pegawai dalam menyelesaikan tugas yang dibebankan kepadanya merupakan dasar yang harus dimiliki setiap pegawai agar dapat mencapai target yang ditetapkan instansi tersebut. Dan diharapkan prestasi kerja tersebut dapat lebih ditingkatkan lagi.

Pada indikator tanggung jawab, seorang pegawai dalam pekerjaan merupakan hal penting dalam penilaian prestasi kerja. Mayoritas responden mendapatkan nilai rata-ratanya dengan kriteria baik. Karena tanggung jawab merupakan kesanggupan seorang pegawai dalam menyelesaikan pekerjaannya tepat waktu dan kesanggupan pegawai dalam memikul resiko atas keputusan yang diambilnya. Untuk itu pegawai harus lebih memupuk rasa tanggung jawab agar lebih baik dalam menjalankan tanggung jawab yang diberikan.

Pada indikator ketaatan seorang pegawai mayoritas responden mendapatkan nilai rata-ratanya dengan kriteria baik. Hal tersebut dikarenakan seorang pegawai harus memiliki kesanggupan untuk mentaati peraturan kedinasan yang berlaku dan kesanggupan pegawai untuk tidak melanggar larangan yang ditentukan. Hal ini dikarenakan seorang pegawai harus memiliki sikap dan moral yang baik sebagai abdi negara.

Pada indikator prakarsa kesigapan dan ketanggapan pegawai dalam melaksanakan tugas tanpa menunggu perintah dari atasan mendapat nilai rata-rata dengan kriteria baik. Hal ini juga harus menjadi kesadaran setiap pegawai agar tidak membuang waktu untuk melaksanakan tugasnya tanpa harus diberi perintah dahulu dari atasan.

\section{b. Pengembangan Karir KPPBC Tipe B Pematangsiantar}

Berdasarkan pembahasan sebelumnya, yaitu pada tanggapan pegawai atas kuesioner yang disebarkan, sebagian besar pegawai merasakan pengembangan karir yang dilaksanakan pada Kantor dan Pengawasan dan Pelayanan Bea dan Cukai Tipe B Pematangsiantar telah baik. Hal tersebut dapat dilihat dari tanggapan para pegawai yang memberikan jawaban baik terhadap pertanyaanpertanyaan yang diajukan.

Indikator dari pengembangan karir meliputi prestasi kerja yang memuaskan, dimana prestasi kerja merupakan pangkal tolak pengembangan karir seseorang. Pada pernyataan prestasi kerja yang memuaskan memberikan dampak positif terhadap pengembangan karir, pegawai menjawab dengan kriteria baik. Hal ini menunjukkan prestasi kerja merupakan salah satu unsur yang menjadi pertimbangan dalam mendapatkan kesempatan untuk mengembangkan karir.

Selanjutnya pengenalan dari pihak lain, dimana atasan atau pimpinan yang berwenang dalam memutuskan layak tidaknya seseorang dipromosikan mengetahui kemampuan dan prestasi kerja pegawai. Hal ini dipertegas dengan jawaban responden yang menjawab dengan kriteria baik. Dalam hal ini diperlukan adanya penilaian yang objektif sehingga pegawai yang benar-benar memiliki kemampuan dan prestasi kerja yang baik mendapatkan hasil yang setimpal berupa kesempatan untuk dipromosikan.

Kesetiaan pada organisasi merupakan salah satu indikator pengembangan karir pegawai, dimana kesetiaan merupakan faktor yang mempengaruhi pengembangan karir pegawai. Hal ini dipertegas dengan jawaban responden yang menjawab dengan kriteria baik. Karena kesetiaan merupakan bentuk apresiasi seseorang kepada organisasi tempatnya bekerja.

Selanjutnya kesempatan untuk tumbuh merupakan kesempatan yang diberikan oleh instansi/organisasi kepada pegawainya untuk meningkatkan kemampuan pegawainya baik melalui pelatihan-pelatihan, kursus dan melanjutkan jenjang pendidikannya. Dengan adanya kesempatan untuk tumbuh, produktifitas pegawai juga akan semakin baik sehingga dalam mengerjakan suatu pekerjaan menjadi lebih efektif dan efisien. Hal ini dipertegas dengan jawaban responden yang mayoritas menjawab dengan kriteria baik. Pada indikator ini perlu adanya perhatian terhadap pegawai senior dimana jenjang pendidikan mayoritas pegawai senior adalah SMA agar mereka juga mendapatkan kesempatan yang sama untuk mendapatkan kesempatan diklat dan pelatihan-pelatihan guna mengembangkan karirnya.

Pada indikator berhenti atas permintaan dan kemauan sendiri, instansi/organisasi memberikan keleluasaan kepada pegawainya untuk memilih tetap bekerja ataupun untuk mengundurkan diri dari organisasi. Hal ini disebabkan pegawai diberi kebebasan untuk membuat keputusan dalam karirnya. Pernyataan tersebut dipertegas dengan jawaban responden yang mayoritas menjawab dengan kriteria baik.

\section{KESIMPULAN DAN SARAN}

\section{Kesimpulan}

a. Dari hasil kuesioner penilaian prestasi kerja pada tabel 7, nilai rata-rata responden adalah 4,00 dengan kriteria baik. Hal tersebut menunjukkan mayoritas pegawai memberikan respon yang positif dan menyatakan baik terhadap penilaian prestasi kerja yang diterapkan KPPBC Tipe B Pematangsiantar.

b. Dari hasil kuesioner pengembangan karir pada tabel 8, dapat dilihat bahwa pengembangan karir yang ada pada Kantor Pengawasan dan Pelayanan Bea dan Cukai Tipe B Pematangsiantar telah dilaksanakan dengan baik. Hal ini dapat dilihat dari mayoritas pegawai yang 
c. memberikan respon positif dengan nilai rata-rata 4,07 dengan kriteria baik.

c. Berdasarkan Analisa Regresi Sederhana diperoleh hasil $\hat{\mathrm{Y}}=0,67+0,98 \mathrm{X}$, maka dapat diartikan bahwa penilaian prestasi kerja berpengaruh positif pada pengembangan karir. Dimana apabila pelaksanaan penilaian prestasi kerja semakin optimal, maka pengembangan karir akan semakin baik pula.

d. Nilai korelasi yang diperoleh yaitu, $r=0,51$ menunjukkan adanya hubungan yang sedang antara penilaian prestasi kerja sebagai variabel bebas terhadap pengembangan karir sebagai variabel terikat. Kesimpulan ini dibuktikan dengan perhitungan koefisien determinasi sebesar 26,01\% dapat dijelaskan dengan penilaian prestasi kerja, dan sisanya $73,99 \%$ dipengaruhi oleh faktor lain seperti motivasi, budaya kerja, tingkat pendidikan dan faktorfaktor lainnya yang tidak dibahas dalam penelitian ini.

e. Hasil uji hipotesis menunjukkan bahwa koefisien korelasi $t_{\text {hit }} 2,52>t_{\text {tab }} 2,10$. Jika $t_{\text {hitung }}>t_{\text {tabel }}$ maka Ho ditolak dan Ha diterima, artinya adanya pengaruh positif antara penilaian prestasi kerja (X) terhadap pengembangan karir pegawai (Y). Hal ini berarti bahwa penilaian prestasi kerja pada Kantor Pengawasan dan Pelayanan Bea dan Cukai Tipe B Pematangsiantar berpengaruh secara positif terhadap pengembangan karir pegawai, sehingga hipotesis yang diajukan penulis adalah dapat diterima.

\section{Saran}

a. Untuk mewujudkan penilaian prestasi kerja yang objektif, organisasi selain harus mempersiapkan penilai yang baik secara mental dan teknis juga harus menetapkan suatu standar penilaian yang jelas.

b. Dalam hal pengembangan karir diperlukan adanya perhatian yang lebih terhadap pegawai senior yang mayoritas jenjang pendidikannya SMA agar mendapatkan kesempatan yang sama dalam mengembangkan karirnya.

c. Mengingat penilaian prestasi kerja berpengaruh positif terhadap pengembangan karir pegawai, diharapkan penilaian dilakukan secara objektif sehingga pegawai merasa prestasi kerja mereka dihargai oleh organisasi.

\section{E. DAFTAR PUSTAKA}

Hariandja, E. Manajemen Sumber daya Manusia. PT Gramedia WidiasaranaIndonesia. Jakarta. 2002.

Hasibuan, Malayu. Sumber Daya Manusia. Bumi Aksara, Jakarta. 2002.

Mondy, R. Wayne. Manajemen Sumber Daya Manusia. Jakarta: Penerbit Erlangga. 2008.

Nasution, M. Manajemen Personalia Aplikasi di Perusahaan. Djambatan. Jakarta. 2004.

Rivai, H. Veithzal Dan Ella Jauvani Sagala. Manajemen Sumber Daya Manusia untuk Perusahaan: Dari Teori ke Praktik. Rajawali Pers: Jakarta. 2009.

Saydam, G. Manajemen Sumber Daya Manusia. PT Gramedia Pustaka Utama. Jakarta. 2005.

Tanjung, H dan Arep, I. Manajemen Sumber Daya Manusia. Universitas Trisakti. Jakarta. 2002. 